\title{
Diet and feeding intensity of sardine Sardina pilchardus: correlation with satellite-derived chlorophyll data
}

\author{
Susana Garrido ${ }^{1, *}$, Radhouan Ben-Hamadou ${ }^{2}$, Paulo B. Oliveira ${ }^{1}$, \\ Maria Emilia Cunha ${ }^{3}$, Maria Alexandra Chícharo ${ }^{2}$, Carl D. van der Lingen ${ }^{4}$
}

\author{
${ }^{1}$ Instituto Nacional de Investigação Agrária e das Pescas - (INIAP/IPIMAR), Avenida de Brasília, 1449-006 Lisbon, Portugal \\ ${ }^{2}$ Universidade do Algarve, FCMA, CCMAR, Campus de Gambelas, 8005-139 Faro, Portugal \\ ${ }^{3}$ INIAP/IPIMAR, CRIP Sul, Avenida 5 de Outubro s/n, 8700-305 Olhão, Portugal \\ ${ }^{4}$ Marine and Coastal Management, Private Bag X2, Rogge Bay 8012, South Africa
}

\begin{abstract}
Spatio-temporal variability of the diet of sardine Sardina pilchardus off Portugal was examined through analysis of the stomach contents of fish collected every $14 \mathrm{~d}$ from the west and south of Portugal during 2003/2004. Dietary composition of the modal sardine length class was assessed by determining the frequency of occurrence and carbon content of identified prey, and these 2 parameters were combined to estimate a modified index of relative importance of prey (mIRI). The most important prey for sardines were zooplankton, comprising crustacean eggs, copepods, decapods, cirripedes and fish eggs, dinoflagellates and diatoms (particularly the toxin-producer genus Pseudo-nitzschia), which together accounted for $>90 \%$ of the estimated dietary carbon. Dietary seasonality was similar for both areas, except that the contribution of phytoplankton was higher for fish from the west Portuguese coast, where upwelling events are stronger and recurrent during spring and summer months. The predominance of prey $<750 \mu \mathrm{m}$ in sardine diet suggests that filter feeding is the dominant feeding mode used in the wild. Feeding intensity was similar for both sexes and for fish of different length classes and was higher on the west coast than in the south, which is probably related to the higher productivity of the west coast. Although there was high inter-annual variability in feeding intensity, this parameter was highest for both areas during spring and winter months. Temporal variability in satellite-derived chlorophyll a matched the temporal variability in the dietary contribution by phytoplankton and of sardine feeding intensity, suggesting further investigation of the potential use of satellite-derived chlorophyll a data as a proxy for sardine feeding intensity.
\end{abstract}

KEY WORDS: Sardina pilchardus $\cdot$ Stomach analysis $\cdot$ Feeding intensity $\cdot$ SeaWIFS

\section{INTRODUCTION}

Sardine Sardina pilchardus is the most abundant pelagic fish in Iberian waters and represents the main target of purse-seine fisheries in Portugal and Spain (ICES 2006). Variations in the abundance, condition and recruitment of the Atlanto-Iberian sardine stock observed over the last decades were found to be related to changes in environmental conditions (Borges et al. 2003, Guisande et al. 2004, Silva et al. 2006), and, within the area of distribution of this stock, there are distinct oceanographic regimes that might explain geographical differences in sardine morphometric characteristics, age structure, population dynamics and maturation patterns (ICES 2000, Carrera \& Porteiro 2003, Silva 2003, Silva et al. 2006). Environmental discontinuities such as temporal and geographical variations in food availability have been proposed to explain differences in sardine maturation patterns between fish in the Mediterranean and southern Iberian Atlantic waters compared to those from western Iberia (Silva et al. 2006). It is likely that sardines living in areas where re- 
current upwelling events provide rich food environments will have different feeding strategies compared to sardines living in less productive environments. Sardines have a highly plastic/flexible feeding behaviour and are able to use filter or particulate feeding over a broad prey size spectrum with high efficiency (Garrido et al. 2007), indicating that they are adapted to feeding in a wide variety of environments. This suggests that their key prey species probably vary geographically, and that differences in feeding intensity and food quality may help in explaining regional differences in sardine ecology, namely growth and reproduction.

The west and south Iberian coasts have different oceanographic conditions, which influence plankton abundance and composition throughout the year. Seasonal variation in plankton communities off the Portuguese coast seem to be due to coastal upwelling, river run-off, seasonal cycles in thermal stratification (summer and late autumn) and vertical convection (winter and early spring) (Cunha 2001), as well as the seasonal influence of oligotrophic oceanic waters over the shelf (Moita 2001). The west coast of Portugal is under the influence of a northerly wind regime that leads to coastal upwelling events from July to September, although sporadic upwelling events of smaller intensity than in the summer may also occur during December and January (Fiúza et al. 1982). Off the south coast, the effects of upwelling are reduced, although upwelling does occasionally occur there under the influence of local westerly winds, or mainly when upwelled waters from the west coast intrude over the southern shelf break following an easterly extension of the equatorward upwelling current (Fiúza 1983, Relvas \& Barton 2002). As a consequence, maxima in phytoplankton biomass are generally found during all seasons off the west coast of Portugal (Moita 2001). Moreover, in that region, the shelf is larger, flatter and has greater thermo-haline stratification than in the south, which is the major reason for the $\mathrm{N}-\mathrm{S}$ differences in plankton composition (Cunha 2001), although inshore-offshore variations in phytoplankton composition appear to be higher than latitudinal variations (Moita 2001).

Sardine condition peaks during late summer (Bandarra et al. 1997), and it is empirically assumed that feeding intensity also peaks during this season. However, examination of the seasonal cycle in sardine feeding and identification of seasonal changes in the relative importance of sardine prey have not yet been performed, and such a study would enable identification of the season responsible for high fish condition in summer that influences the following spawning season.

Finally, the observed correspondence between the ambient food environment and sardine stomach contents (Varela et al. 1990, Bode et al. 2003) suggests that this species is essentially a filter feeder whose diet reflects local plankton composition. If this assumption is true then routine measures of plankton productivity, such as remotely sensed chlorophyll a (chl a), could be used to study spatial and temporal variability in sardine feeding intensity, which would be an important tool, since stomach content analysis represents a laborious and time-consuming task that is difficult to perform at a large scale (Cunha et al. 2005).

The objective of the present study was to examine the diet of sardine from 2 areas off the Portuguese coast characterized by different hydrological regimes, with the intention of: (1) identifying the most important prey items, (2) studying seasonal variation in sardine diet, (3) examining sardine feeding intensity in relation to age and sex, and (4) assessing whether remotely sensed chl a data provide a good estimation of sardine feeding intensity, particularly of phytoplankton prey.

\section{MATERIALS AND METHODS}

Samples comprising $\sim 70$ sardine Sardina pilchardus were obtained every $14 \mathrm{~d}$ from purse-seiners fishing off northwest (Peniche) and southern (Portimão) Portugal from January 2003 to March 2004 (Fig. 1). The

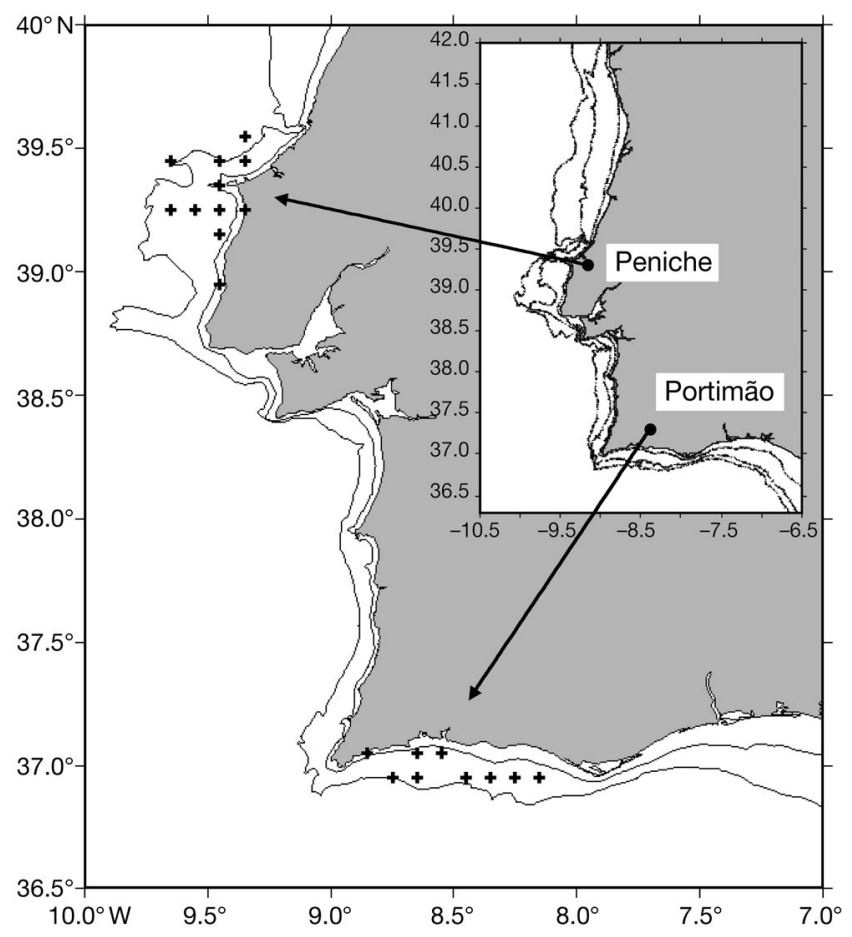

Fig. 1. Map of the Portuguese continental coast, showing the sampling locations of Sardina pilchardus in the fishing areas of Peniche and Portimão (note that several samples were taken from the same location) 
location of the trawls was provided by the fisherman, and data on total length, gutted weight (fish weight minus viscera), sex, gonad maturity stage and indices of fat content were recorded for each sardine. The stomach of each fish was removed and weighed individually, cut open and the contents removed and weighed, and the empty stomach was weighed again. Only the content of the cardiac stomach and the fundulus of the stomach were analysed, while the contents of the oesophagus, pyloric stomach and intestine were not extracted, to avoid bias due to differential rates of prey digestion, gut passage times and codend feeding. All weight measurements were made to the nearest $0.1 \mathrm{mg}$. Stomach contents from each fish were then individually deep-frozen for subsequent prey analysis. Microscopic analysis of food items was conducted for subsamples of 10 stomachs per sample and was restricted to sardines of the modal length class in the fishery $(18 \mathrm{~cm})$, in order to avoid size-based differences in diet. Contents from the 10 subsamples were combined, and an aliquot comprising $50 \%$ of this was used to identify and count prey items. The aliquot was first weighed, then diluted in a known volume of water (proportional to the weight of the aliquot) and filtered through a $200 \mu \mathrm{m}$ sieve, in order to facilitate the identification of the food items; then the 2 size fractions were analysed separately. All prey were identified to the lowest possible taxa; those $<200 \mu \mathrm{m}$ were identified using an inverted microscope at a magnification of $400 \times$, whereas those $>200 \mu \mathrm{m}$ were examined using a stereomicroscope at a magnification of $80 x$. Digital pictures of prey were taken using the software Zeiss KS100 3.0 on the inversion microscope and the software Leica IM 500 on the stereomicroscope, and the major and minor axes of each prey item were recorded and converted into volumetric estimates using equations that approximated the appropriate shape (generally spherical or ellipsoidal). In order to determine the relative importance of prey, their carbon content was estimated using equations given in Smayda (1978) for phytoplankton, Huntley \& Lopez (1992) for crustacean eggs, Lindley (1998) for decapods, Verity \& Langdon (1984) for tintinnids, van der Lingen (1998) for crustacean nauplii, copepods and cladocerans and Napier (1993) for fish eggs.

The maximum dimension of identified prey was used to group prey items into size classes; chainforming diatoms were assigned to a size class based on the maximum dimension of single cells, since most phytoplankton cells were found as individuals in stomach contents and the length of the chain was unknown. The frequency of occurrence, percentage contribution by number and percentage contribution to dietary carbon of each prey size class were then calculated.
A modified index of relative importance of prey (mIRI; Hayse 1990) was used to examine spatial and temporal variability in sardine dietary composition:

$$
\operatorname{mIRI}_{i}=\% F_{i} \times \% C_{i}
$$

where $\% F$ is the frequency of occurrence (determined as the number of stomach samples in which a given prey was found versus the total number of stomach samples) and $\% C$ is the percentage contribution to total carbon content of a given prey (i) in the stomach samples.

For this analysis, copepod eggs, copepod egg sacs and eggs of other crustaceans were grouped together, and the different species of Temora and Centropages were grouped to genus. Sardine and other spherical fish eggs were grouped together, whilst Engraulis eggs were recorded separately because their oval shape is easy to recognize and distinguish from other fish eggs.

Seasonality in dietary composition at the 2 sample sites (Peniche and Portimão) was assessed using hierarchical clustering analysis of the $14 \mathrm{~d}$ relative contribution of prey groups to dietary carbon, with BrayCurtis similarities and Euclidean distances being calculated and the flexible linkage agglomeration considered following Legendre \& Legendre (1998). Dominant prey groups were selected for each area, and an empirical threshold criterion was applied to cumulative mIRI values over seasons.

Feeding intensity (FI) was calculated using the following expression:

$$
\mathrm{FI}=\frac{\text { stomach content weight }}{\text { (total weight }- \text { gonad weight) }} \times 100 \%
$$

Feeding intensity was standardized in order to account for differences in the size of the stomach in relation to fish size. To investigate for differences in feeding intensity between sexes and among sardine size classes 2 approaches were used: generalized linear modelling (GLM) and correlation analysis. GLM was used to test for differences in feeding intensity between sexes and among size classes, using sex as a fixed factor and length as a continuous covariate with an identity link function. To investigate differences in the variation of feeding intensity among sexes, separate contingency matrices for males and females that contained the average stomach content weight for each length class and each $14 \mathrm{~d}$ sample were created, and the unfolded matrices were compared using the Mantel test (Legendre \& Legendre 1998). To identify differences of the variation of stomach content weight of fish of different length classes, a contingency matrix was built, with each entry being the average stomach content weight for each length class and $14 \mathrm{~d}$ sample. Length classes corresponding to 12, 13, 14 and $23 \mathrm{~cm}$ were ignored due to insufficient data, and the Spear- 
man rank correlation statistic was used to compare pairs of either length classes or sexes, and was tested by 10000 permutations. Temporal differences in sardine feeding intensity at each sampling location were investigated using an ANOVA conducted on normalised (log-transformed) stomach weight data from $14 \mathrm{~d}$ samples, and an a posteriori Tukey HSD test ( $\mathrm{p}<$ 0.05) for unequal sample sizes was used to identify significant differences in mean values.

To assess whether remotely sensed chlorophyll could be used to proxy sardine feeding intensity and food quality, we extracted chlorophyll data from $9 \mathrm{~km}$ resolution SeaWiFS chl a concentration standard mapped images (L3SMI product; Thomas \& Franz 2005) for the fishing areas from which sardine were sampled. Chl a from daily images was compared with: (1) total carbon content of autotrophic phytoplankton cells identified in the stomachs and (2) average values of feeding intensity for each $14 \mathrm{~d}$ sample using Model II regression; the reduced major axis (RMA) method minimizes the sum of the cross-products of the differences on both axes, accounting simultaneously for the errors in both dependent and independent variables (Sokal \& Rohlf 1995). When chlorophyll data were not available for a particular fishing location and date, the value of the nearest neighbourhood (closest $9 \mathrm{~km}$ block) was used. Considering the anisotropy patterns on SeaWIFS data (Kiyofuji et al. 2006), variograms of chlorophyll distribution were analysed for the sampling area (authors' unpubl. data), showing that the gradient in chlorophyll concentration is higher in onshore-offshore direction than in latitude in the case of the west coast or longitude in the case of the south coast of Portugal. Therefore, we used the chlorophyll data of the nearest pixel in the northern direction for Peniche and in the eastern direction for Portimão, when no data were available for the exact location and day of the catch to compare with sardine diet. The Spearman correlation coefficient was used to assess significance of derived linear regressions and was tested by 10000 permutations of the chlorophyll averages.

All data and statistical analyses were performed using MATLAB software (Version 6.5; MathWorks).

\section{RESULTS}

\section{Diet composition}

\section{Relative importance of prey}

The mean length, frequency of occurrence $(\% F)$, contribution to dietary carbon and mean index of relative importance (mIRI) for all prey identified from sar- dine Sardina pilchardus stomachs at Peniche and Portimão are given in Appendix 1 (available as Supplementary Material online at www.int-res.com/articles/ suppl/m354p245_app.pdf. Phytoplankton and zooplankton prey occurred in every stomach sampled, and fish eggs occurred in $69 \%$ of the Portimão samples and $67 \%$ of the Peniche samples. Zooplankton was the most important prey at both locations (mIRI values of 6300 and 5600 for Peniche and Portimão, respectively), with phytoplankton the second most important prey group at Peniche (mIRI of 1941) and fish eggs the second most important prey group at Portimão (mIRI of 2065).

Unidentified crustacean eggs plus copepod eggs and copepod egg sacs not only had the highest frequency of occurrence, but were also the most abundant in stomach contents and had the highest relative importance to sardine diet of all zooplankton prey groups in both areas (see Appendix 1). Copepods (adults and copepodites) occurred in every stomach sample, and calanoid copepods (represented by a higher diversity of genera than the other copepod orders, but comprising mainly Centropages spp.) were the most important group, followed by harpacticoid copepods (primarily Euterpina spp.) and poecilostomatoid copepods (Oncaea spp.). Cirripedes followed copepods in importance to sardine diet, while other zooplankton groups had very low significance.

Fish eggs were present in sardine stomach contents in low numbers, but their high relative carbon content resulted in high mIRI values for this type of prey (see Appendix 1). Eggs of Engraulis encrasicolus were only present in samples from Portimão, where they made a low average contribution to sardine diet. Eggs clearly identified as sardine eggs occurred in both areas, but had a higher relative importance in samples from Portimão.

Dinoflagellates and diatoms occurred in every stomach sampled, but dinoflagellates made a larger contribution to sardine diet than did diatoms for both areas (see Appendix 1), and the importance of diatoms and dinoflagellates to the diet was higher in fish from Peniche than from Portimão. The most frequently encountered $(\% F)$ dinoflagellates were Ceratium spp., Dinophysis caudata and Protoperidinium spp. Whereas Protoperidinium and Ceratium were the most important dinoflagellates in terms of dietary carbon in both regions, dinoflagellate cysts were only important to the diet of fish from Portimão. The diatom Paralia sulcata had the highest $\% F$ for fish from both areas, followed by Thalassiosira, Pseudo-nitzschia and Coscinodiscus in Peniche and Diploneis and Thalassiosira in Portimão. Pseudo-nitzschia made the largest contribution to dietary carbon and had the highest mIRI value for both areas, although its importance was much greater in Peniche than in Portimão. 
Prey size classes in stomachs

The relative contribution to sardine dietary carbon by prey size (Fig. 2) showed that 2 modes (50 to 150 and 1000 to $1500 \mu \mathrm{m})$ clearly dominated stomach contents of fish from both Peniche and Portimão. Small prey from 50 to $150 \mu \mathrm{m}$ made the highest contribution to dietary carbon, contributing $40 \%$, on average, to dietary carbon for fish from Peniche and $30 \%$ for those from Portimão. These small size classes represented $85 \%$, on average, of the number of prey in stomachs of fish from Peniche and $79 \%$ of the prey in fish from Portimão, and correspond mainly to crustacean eggs ( $\pm 117 \mu \mathrm{m}$ in length) and phytoplankton of the genera Ceratium $( \pm 120 \mu \mathrm{m}$ in length), Protoperidinium $( \pm 90 \mu \mathrm{m}$ in length) and Pseudo-nitzschia $( \pm 69 \mu \mathrm{m}$ in length of single cells, although chains are expected from this size up to $300 \mu \mathrm{m})$. The larger mode (1000 to $1500 \mu \mathrm{m}$ ) comprises primarily the copepod Centropages and fish eggs, and contributed $24 \%$ of the dietary carbon in sardines from Peniche and $34 \%$ in fish from Portimão.

Seasonal variation in prey composition and relative dietary importance

Sardine prey composition shows seasonal variation at both Peniche and Portimão, particularly regarding the relative importance of phytoplankton to dietary carbon, which was more important over summer (June to September), especially at Peniche (Fig. 3). Prey groups that made a major contribution to dietary carbon throughout the year included copepods (adults, copepodites and nauplii), which contributed $24 \pm 5.3 \%$ of dietary carbon, crustacean (including copepod) eggs (23 $\pm 5.2 \%$ ), fish eggs $(23 \pm 8.0 \%)$, dinoflagellates $(14 \pm 4.7 \%)$, cirripedes $(6 \pm 3.2 \%)$, diatoms $(4 \pm 2.0 \%)$ and decapods $(2 \pm 1.8 \%)$. Together, these groups accounted for $>90 \%$ of the estimated carbon content of identified prey in sardines from both areas.

The cluster analysis conducted on the percentage contribution to dietary carbon by the various prey types identified 9 categories for Peniche (Fig. 4a) and 8 categories for Portimão (Fig. 4b); these categories represented groups of $14 \mathrm{~d}$ samples that were similar in terms of prey percentage contribution to dietary carbon.

The mIRI was estimated for each prey type for each category, which allowed identification of the most important prey per category for each area. At Peniche,
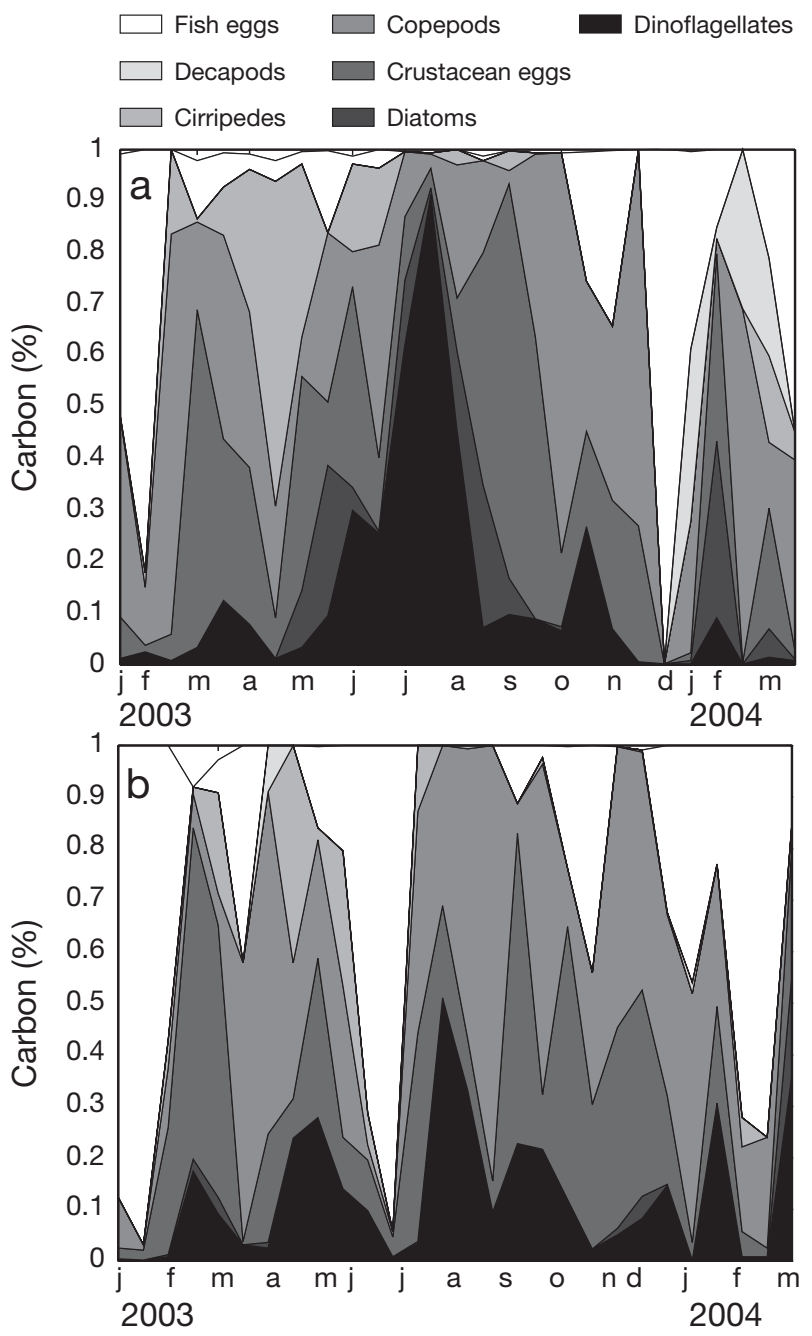

Fig. 3. Sardina pilchardus. Cumulative percentage contribution to dietary carbon by prey category in the stomachs of $\sim 18 \mathrm{~cm}$ sardines collected every $14 \mathrm{~d}$ from (a) Peniche and (b)Portimão 

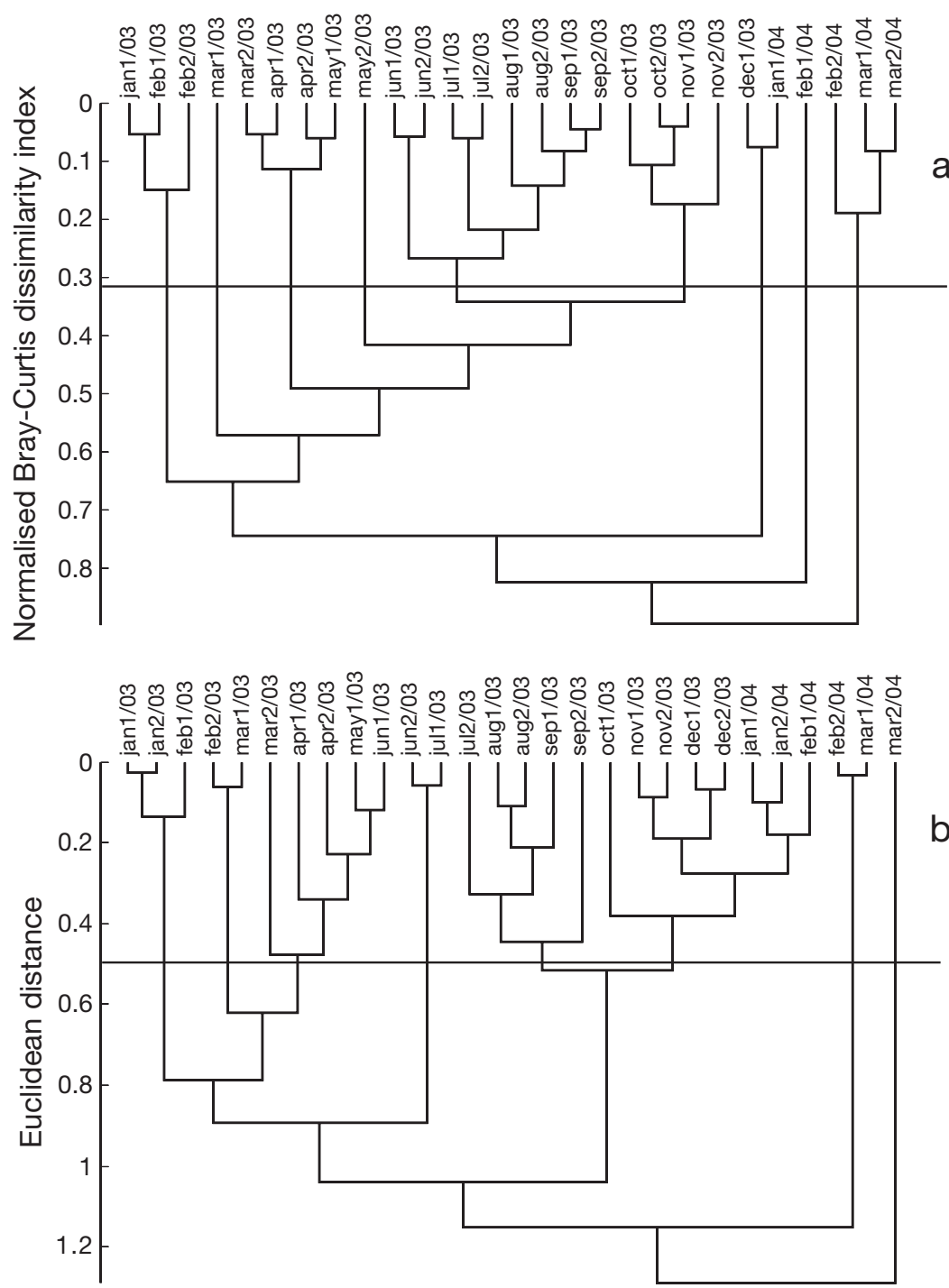

Fig. 4. Sardina pilchardus. Cluster analysis of prey composition in terms of contribution to dietary carbon for stomach samples collected every $14 \mathrm{~d}$ ('1' represents the first and ' 2 ' the second $14 \mathrm{~d}$ period of each month) from Peniche (a) and Portimão (b) over the period January 2003 to March 2004

11 prey types were identified as the most important during at least one of the categories, whilst 9 prey types were identified as the most important at Portimão (Table 1). Protoperidinium, Pseudo-nitzschia, crustacean eggs, Euterpina, Oncaea, Centropages, cirripedes and fish eggs were identified as the most important prey for both areas; Ceratium, unidentified copepods and decapod brachyura zoea were important for sardines collected off Peniche, whilst Temora was important for sardines collected off Portimão.

Fish eggs were one of the most important prey types during winter (mostly December until February) at both locations, whereas prey composition was more variable during spring. In 2003, samples collected at Peniche during spring (March to May) were grouped into 3 categories. Crustacean eggs, unidentified copepods and fish eggs dominated the sardine diet in early March; cirripedes and crustacean eggs dominated from late March to early May; and the diatom Pseudo-nitzschia and copepods of the genus Centropages were the most important prey during late May. During the late winter/early spring of 2004 (late February to March), the prey composition of fish from Peniche differed from that seen in spring 2003, and was dominated by fish eggs, decapod Brachyura zoea and Centropages.

Dietary samples collected from Portimão during the late winter/early spring of 2003 were grouped into 2 categories; the first, taken in late February and early March, was dominated by crustacean eggs, cirripedes and Protoperidinium, whereas fish eggs, Centro-

b pages, Oncaea and Euterpina were also important from late March to early June. Samples collected during the spring of 2004 were also grouped into 2 groups according to prey composition; the diet in late winter (late February and early March) was dominated by fish eggs, Centropages and Temora, while in late March fish eggs and crustacean eggs had a similar relative importance to the dinoflagellate Protoperidinium and the diatom Pseudonitzschia.

Prey composition during the autumn/ early winter months (early October to early February) in Peniche was dominated by crustacean eggs and the copepods Centropages and Oncaea and was quite different from the prey composition observed in late winter months. In contrast, the prey composition of fish from Portimão sampled during autumn and winter was similar and was dominated by fish and crustacean eggs, followed by several copepod genera (Oncaea, Temora, Centropages and Euterpina). During summer (June until September), crustacean eggs, 3 phytoplankton genera (the diatom Pseudo-nitzschia and the dinoflagellates Protoperidinium and Ceratium) and the copepod Euterpina were the most important prey. The prey composition of sardines from Portimão varied during summer, with fish eggs dominating the diet until early July and crustacean eggs, Oncaea and Protoperidinium being the most important prey from late July until September. 
Table 1. Sardina pilchardus. Percent modified index of relative importance (mIRI) of the most important prey groups in the diet of sardine collected from Peniche and Portimão between early January 2003 (Jan1) and late March 2004 (Mar2). n.i.: not identified

\begin{tabular}{|c|c|c|c|c|c|c|c|c|c|}
\hline & Jan1-Feb2 & Mar1 Ma & Mar2-May1 & May2 & Jun1-Sep2 & Oct1-Nov2 & Dec1-Jan1 & Feb1 & Feb2-Mar2 \\
\hline \multicolumn{10}{|l|}{ Peniche } \\
\hline Ceratium spp. & 0.0 & 0.0 & 19.3 & 82.7 & 1481.5 & 170.6 & 0.0 & 18.4 & 0.0 \\
\hline Protoperidinium spp. & 3.2 & 96.4 & 371.3 & 432.8 & 1394.8 & 628.3 & 0.0 & 427.1 & 39.1 \\
\hline Pseudo-nitzschia spp. & 0.0 & 0.2 & 207.5 & 2905.6 & 845.2 & 0.0 & 14.5 & 3427.2 & 121.1 \\
\hline Crustacean eggs & 481.6 & 6541.4 & 2783.6 & 1230.4 & 3199.7 & 2101.5 & 83.0 & 3625.3 & 848.2 \\
\hline Copepods n.i. & 825.4 & 1674.8 & 4.2 & 405.8 & 57.6 & 219.8 & 0.0 & 0.0 & 168.5 \\
\hline Euterpina spp. & 192.5 & 9.5 & 1072.4 & 19.1 & 1196.0 & 309.8 & 3.2 & 17.6 & 385.1 \\
\hline Oncaea spp. & 1924.1 & 0.7 & 51.2 & 2.3 & 171.8 & 1579.5 & 0.0 & 15.5 & 89.3 \\
\hline Centropages spp. & 0.0 & 17.1 & 98.8 & 2837.9 & 3.8 & 2181.1 & 1097.1 & 103.6 & 1314.7 \\
\hline Cirripedes & 424.6 & 59.6 & 3329.6 & 0.0 & 431.5 & 0.0 & 0.2 & 0.0 & 744.4 \\
\hline Brachyura zoea & 9.2 & 0.0 & 0.0 & 0.0 & 0.0 & 0.0 & 1673.6 & 215.9 & 1037.8 \\
\hline Fish eggs & 2944.4 & 1137.5 & 409.1 & 1585.0 & 27.6 & 740.3 & 6910.6 & 1516.5 & 1690.8 \\
\hline \multicolumn{10}{|l|}{ Portimão } \\
\hline Protoperidinium spp. & 0.5 & 1020.8 & 754 & & 196.9 & 1423.4 & 420.1 & 11.6 & 3047.2 \\
\hline Pseudo-nitzschia spp. & 0.0 & 42.6 & & .0 & 0.1 & 0.0 & 0.0 & 0.0 & 1886.8 \\
\hline Crustacean eggs & 960.2 & 5852.2 & 1405 & & 675.4 & 2683.1 & 2622.4 & 326.4 & 2540.1 \\
\hline Euterpina spp. & 84.3 & 33.8 & 601 & & 133.8 & 418.6 & 242.8 & 314.4 & 35.2 \\
\hline Oncaea spp. & 52.4 & 10.6 & 698 & & 16.2 & 1629.6 & 776.9 & 114.4 & 14.4 \\
\hline Temora spp. & 0.0 & 0.0 & 78 & & 0.0 & 179.0 & 604.6 & 606.5 & 179.3 \\
\hline Centropages spp. & 169.2 & 78.3 & 707 & & 7.6 & 23.3 & 504.0 & 483.5 & 0.0 \\
\hline Cirripedes & 58.9 & 1031.6 & 846 & & 314.9 & 109.5 & 9.1 & 144.3 & 0.0 \\
\hline Fish eggs & 8059.2 & 158.8 & 943 & & 8240.1 & 45.9 & 1608.6 & 7410.1 & 1498.5 \\
\hline
\end{tabular}

Digenetic trematode parasites were frequently found in sardine stomach contents from both regions $(\% F=93$ and $67 \%$ for Portimão and Peniche, respectively), as was terrestrial pollen $(\% F=\sim 60 \%$ for both areas; see Appendix 1).

The numerical abundance of identified prey was highly variable and ranged from 147 to 7466070 prey items per stomach. There was a significant relationship between average stomach content weight and prey carbon content when samples from both areas were combined ( $\left.\mathrm{p}<10^{-5}, \mathrm{r}^{2}=0.73, \mathrm{n}=56\right)$, with zooplankton prey being primarily responsible for this relationship, followed by ichthyoplankton prey, whereas the carbon content of ingested phytoplankton was not significant in explaining variation in the stomach content weight.

\section{Feeding intensity}

Sardine feeding intensity (FI) was examined for a total of 3599 fish, and its relation to sex and fish length was assessed. The Spearman rank correlation showed that variations in FI between sexes $(r=0.89$ for Peniche and $r=0.94$ for Portimão) or for fish of different length classes (from 14 to $22 \mathrm{~cm}$; $r=0.80$ for Peniche and $\mathrm{r}=$ 0.90 for Portimão) were synchronous. Results of the GLM analysis showed that sex or the interaction between sex and length classes were not significant in explaining feeding intensity $(\mathrm{p}>0.1)$, while fish length significantly affected the average feeding intensity
( $\mathrm{p}<0.005)$, with larger fish having a slightly higher feeding intensity than smaller individuals (slope = 0.11). Results of the ANOVA indicated that FI varied significantly ( $p<0.001)$ for both areas (Fig. 5). FI in fish from Peniche was higher than in those from Portimão for all seasons, and the seasonal variation in FI was higher at Peniche than at Portimão.

Maximum FI values were obtained during winter and spring, particularly during late February 2004 and late May 2003 in fish from Peniche, when copepods and decapods for February and Pseudo-nitzschia, Centropages, crustacean eggs and fish eggs for May dominated sardine stomach contents, and from the end of February to March 2003 for Portimão, when dietary carbon was dominated by crustacean eggs, Protoperidinium and cirripedes (Table 1). Minimum FI values were obtained during winter of 2003 for both areas, and FI during winter of 2004 was clearly higher than during the winter of the preceding year in both areas.

\section{Feeding intensity, ingested phytoplankton and satellite-derived chlorophyll data}

Estimates of chl a concentration obtained from satellite remote sensing for the same spatio-temporal locations as trawls from which sardine samples were collected were compared with the calculated carbon content of autotrophic phytoplankton in sardine stomachs (Fig. 6a) and with the average FI (Fig. 6b) of $14 \mathrm{~d}$ 

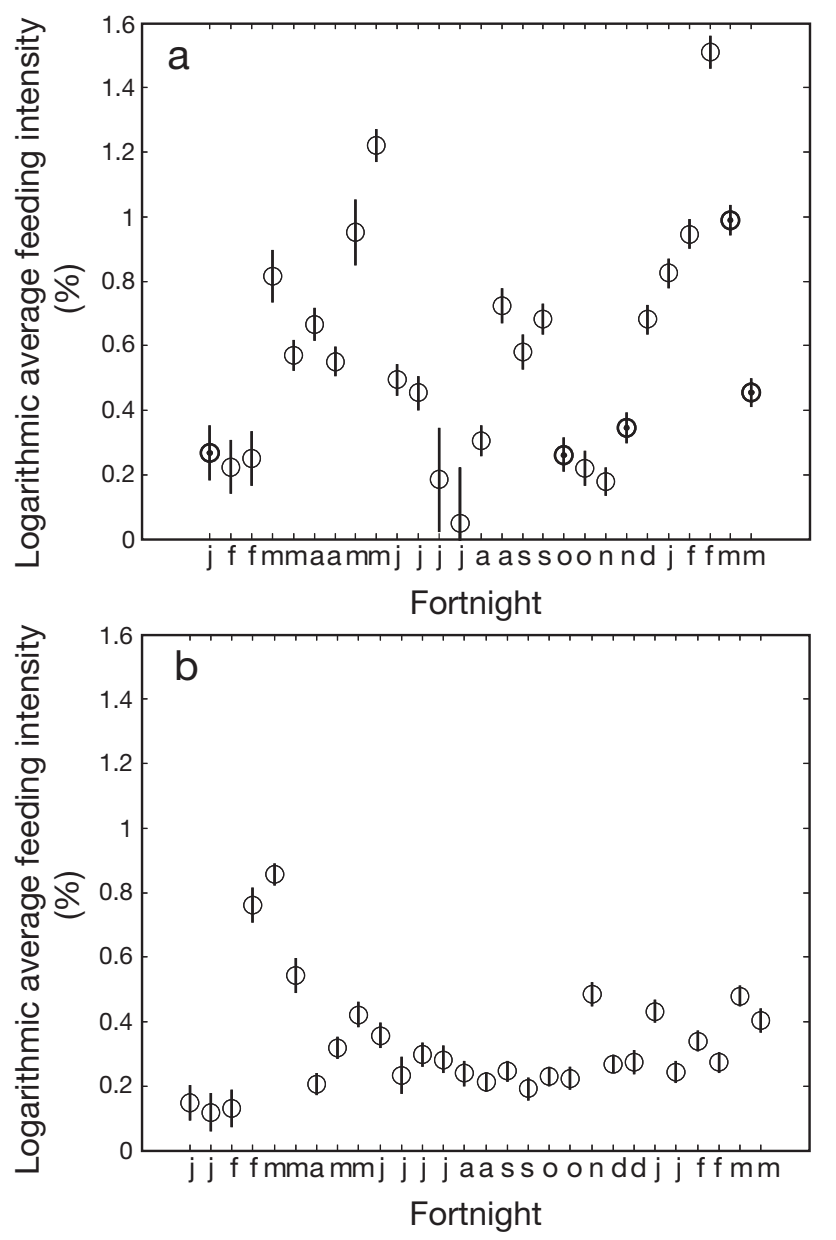

Fig. 5. Sardina pilchardus. Tukey test results of the $14 \mathrm{~d}$ (Fortnight) variation of feeding intensity $[\log (x+1)]$ in (a) Peniche and (b) Portimão from January 2003 to March 2004. Error bars: $\pm \mathrm{SD}$

samples collected at Peniche and Portimão. Significant positive relations were found between chl a concentration and the carbon content of autotrophic phytoplankton $(\mathrm{r}=0.57, \mathrm{p}=0.0008)$, as well as between chl a concentration and average FI $(r=0.45, \mathrm{p}=0.0081)$, indicating that chlorophyll data can be used to roughly estimate the amount of plankton ingested by sardines (Fig. 6).

\section{DISCUSSION}

\section{Major dietary items}

Results from the present study show that Iberian sardines Sardina pilchardus have a diverse diet, with dinoflagellates, diatoms, crustacean eggs, copepods (adults, copepodites and nauplii), decapods, cirripedes and fish eggs accounting for $>90 \%$ of the dietary car-
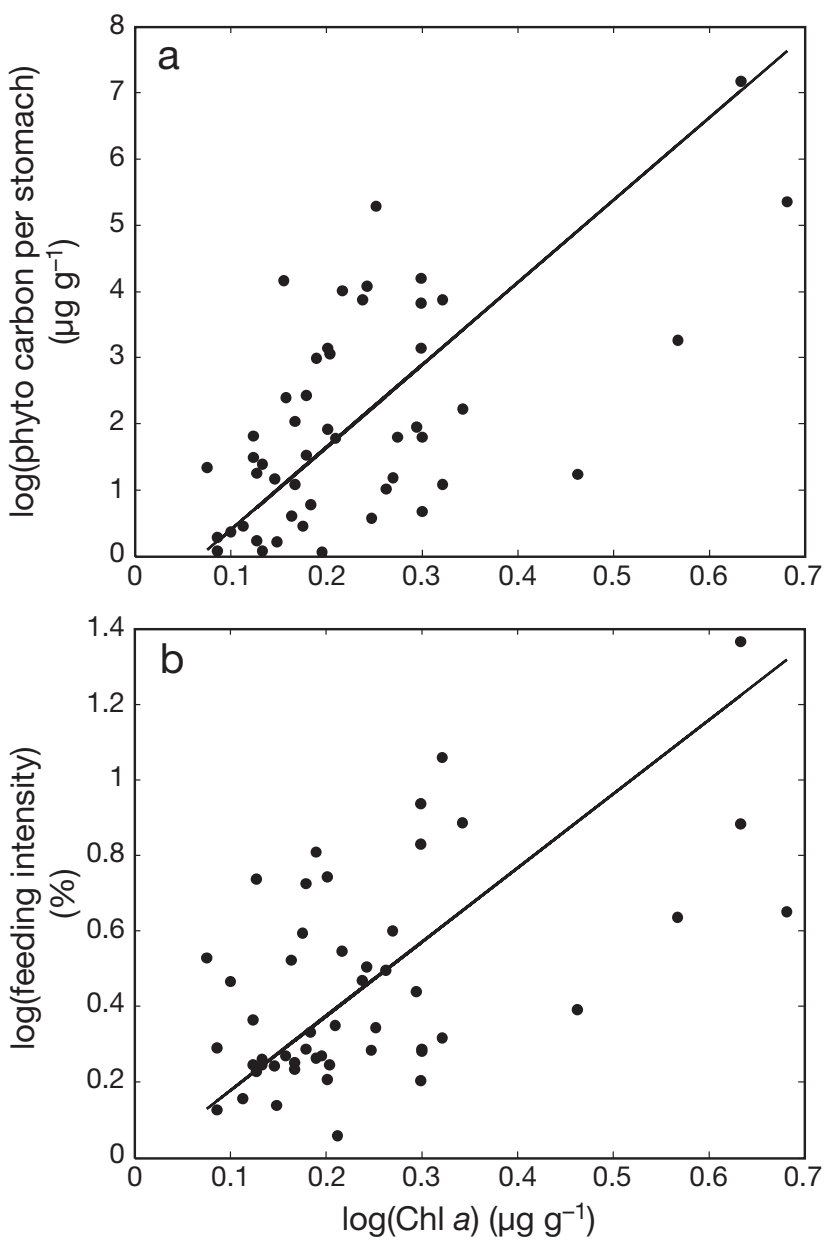

Fig. 6. Sardina pilchardus. Reduced major axis regression between remotely sensed chlorophyll a concentration and (a) the carbon content of phytoplankton prey in sardine stomachs and (b) the feeding intensity of sardines collected from Peniche and Portimão (combined) over the period January 2003 to March 2004

bon of the identified prey in every stomach sample from the west and south coasts of Iberia. These results are in accordance with previous stomach content (numerical and volumetric estimates) and stable isotope studies of the Iberian sardine diet (Varela et al. 1988, 1990, Bode et al. 2003, Garrido 2003), although the dietary contribution of fish eggs was significantly higher in the present than in earlier studies. In general, zooplankton are an important dietary component throughout the year, whereas fish eggs are mostly important during winter, and phytoplankton are particularly important during spring and summer for sardines living in the upwelling region off the Iberian west coast. Differences in dietary composition between winter and early spring in 2003 and 2004 for fish from both areas show that sardine diet has significant interannual variability. In particular, the mIRI identified that the most important prey groups for sardine diet 
were crustacean eggs, the copepods Euterpina, Oncaea, Centropages and Temora, fish eggs, the dinoflagellates Ceratium and Protoperidinium, the toxinproducer diatoms of the genus Pseudo-nitzschia, cirripedes and the decapods Brachyura zoea.

Zooplankton was a significant source of food throughout the year, with similar importance for sardine diets in both areas, and crustacean eggs, copepods and cirripedes contributed the bulk of zooplankton dietary carbon. The high contribution of crustacean eggs to dietary carbon seems to indicate that this type is the most important prey for sardines, although their contribution might be overestimated, since copepod eggs have been reported to survive passage through clupeoid digestive tracts (Flinkman et al. 1994).

\section{Egg cannibalism}

Fish eggs were one of the most important prey types for sardines in both areas, especially during winter, which is the sardine spawning season. Fish eggs were also reported in sardine stomachs by previous studies (Silva 1954, Varela et al. 1988, Garrido 2003). It was not possible to identify the majority of the fish eggs found, but most ranged from 900 to $1000 \mu \mathrm{m}$ and probably correspond to unfertilized or Stage 1 sardine eggs, since the eggs of co-habiting species such as Trachurus trachurus, Scomber scombrus, S. japonicus, Macrorhamphosus spp. and Capros aper are generally smaller.

Egg cannibalism has been proposed as a densitydependent, self-regulatory mechanism in other clupeoid species (Szeinfeld 1991). However, the increased importance of eggs in early winter, when zooplankton availability is lower, particularly in the south, suggests that sardines may be able to compensate for reduced food availability by feeding on their own eggs and/ or the eggs of other fish species. During the spawning season (October until March) sardines were found with an average of 42 eggs per stomach, equivalent to 688 eggs $\mathrm{kg}^{-1}$ fish. The average number of eggs eaten per kilogram of sardine per day can be estimated using the equation proposed by Hunter \& Kimbrell (1980):

$$
C=\mathrm{EE} g t
$$

where $C$ is the mean number of eggs eaten per kilogram of fish during time $t$, EE is the mean number of eggs observed per kilogram of fish mass, $g$ is the gastric evacuation rate for eggs and $t$ is the duration of feeding. If sardines show a similar gastric evacuation rate for eggs to that reported for northern anchovy Engraulis mordax fed their own eggs $\left(-0.701 \mathrm{~h}^{-1}\right.$; Hunter \& Kimbrell 1980), they would be able to complete egg digestion in approximately $2 \mathrm{~h}$. Assuming that sardines use particulate feeding to prey on fish eggs (Garrido et al. 2007) and do so only during daylight hours, they would have the ability to ingest at least 4 times the average amount of eggs per day estimated from stomach contents during the spawning season (there are about $9 \mathrm{~h}$ of daylight during winter off the Portuguese coast); hence, the average number of eggs eaten per kilogram of sardines per day is estimated as 4344 eggs $\mathrm{kg}^{-1}$ fish.

Using estimates of sardine reproductive parameters obtained for fish collected off the Portuguese coast in recent years, namely a batch fecundity of 14255 eggs per spawn, a spawning fraction of $10 \%$ and a proportion of females in the adult population of 0.61 (ICES 2003), enables the calculation of egg mortality arising from cannibalism exerted by adult sardines. The resultant value of $30 \%$ is within the range of estimates calculated for various anchovy species; Hunter \& Kimbrell (1980) estimated that $32 \%$ of natural mortality of northern anchovy eggs was due to cannibalism, Alheit (1987) estimated a value of $22 \%$ for Peruvian anchovy Engraulis ringens, and Valdés et al. (1987) estimated a value of $70 \%$ for Cape anchovy Engraulis capensis (this very high value may have arisen from limited sampling in an area of unusually high egg density; a later study estimated an average value of $6 \%$; Szeinfeld 1991). However, the first 2 of these studies conducted on anchovy considered that feeding occurred over the entire $24 \mathrm{~h}$ period and the third study considered that feeding occurred over a $15 \mathrm{~h}$ period, not only during daylight as we did for sardine. If we also assume $24 \mathrm{~h}$ feeding by sardine, it would lead to an estimation $81 \%$ of sardine egg mortality being due to cannibalism.

If, however, the gastric evacuation rate of Iberian sardines is slower than the $-0.701 \mathrm{~h}^{-1}$ documented for northern anchovy (evacuation rates ranging from -0.09 to $-0.27 \mathrm{~h}^{-1}$ have been reported for Sardinops sagax off South Africa; van der Lingen 1998), then the estimated number of eggs eaten per kilogram per day (4344) will be an overestimate, as will the estimate of cannibalism-induced egg mortality. The dependence of these estimations upon feeding duration and gastric evacuation rate of Iberian sardine strongly suggests that further work be conducted on this species in order to refine such estimates.

The assessment of the effect of cannibalism by adult sardines on their eggs is highly important because this might be a significant source of mortality. Previous laboratory experiments (Garrido et al. 2007) have shown that sardines select fish eggs in preference to other prey, including larger fish larvae (that were not seen in stomach contents examined during this study), when fed cultured, mixed prey assemblages. Sardine also showed selection for copepods and decapods over other zooplankton prey when fed wild, mixed prey 
assemblages (Garrido et al. 2007), and the selection of preferred food items by fish can have a marked effect on plankton communities (Brooks \& Dodson 1965).

\section{Phytoplankton prey and potential transfer of toxicity to higher trophic levels}

Phytoplankton prey were especially important for sardine off the west coast of Portugal during summer months, when the occurrence of diatom (mostly of the genus Pseudo-nitzschia) blooms that are associated with upwelling events is concomitant with stratified waters that stimulate the growth of dinoflagellates (Moita 2001). This resulted in phytoplankton contributing from 74 to $93 \%$ of the dietary carbon of sardine collected from Peniche during July 2003, and phytoplankton had a higher contribution in the sardine diet throughout the year in this area than did fish from the south Iberian coast.

The high concentrations of the toxin-producing diatom Pseudo-nitzschia observed in sardine stomachs collected off Peniche from May to late September have been related to the accumulation of domoic acid in sardine viscera, making them potential vectors of this toxin to higher trophic levels (Costa \& Garrido 2004). Stomachs of sardines collected off Portimão do not show such high concentrations of Pseudo-nitzschia, since the Portuguese south coast does not experience such strong and frequent upwelling as is observed off the west coast. However, phytoplankton such as the dinoflagellates Dinophysis acuta and D. acuminata that are known toxin producers are accumulated at high concentrations in sardine stomachs from both regions (see Appendix 1), implying that sardines might also function as vectors of diarrhetic shellfish poison for higher trophic levels, which should be further examined.

Some phytoplankton groups such as dinoflagellate cysts were frequently encountered and abundant in sardine stomachs, especially for fish from south Iberia. Although it is generally assumed that the digestion by fish of resting stages of phytoplankton is not possible, dinoflagellate cysts could be a good food source because of their lipid reserves, and further work to examine whether predators are able to assimilate cysts is required (Persson 2000).

\section{Feeding seasonality}

Contrary to previous perceptions we propose that summer months do not represent the main feeding season for Iberian sardines, but instead the season when fish increase their fat reserves because they are not involved in reproduction. In our study, summer did not correspond to a period of increased plankton availability for either the west or south coast of Portugal, as shown by remotely sensed chlorophyll data, nor to a peak in sardine feeding intensity. This was also observed during 2002, when sardines collected during spring months had higher feeding intensity than those collected during the summer (Garrido 2003). Variation in feeding intensity is more strongly related to plankton production than to fish reproductive condition, which is confirmed by the lack of difference in feeding intensity between sexes, and also explains why the feeding intensity of sardines from the west coast (an upwelling area) is higher than that in sardines from the south coast. The difference of feeding intensity between sardine size classes may be due to different feeding behaviours or filtering efficiencies of small sardines when compared to larger individuals (van der Lingen 1998, Bode et al. 2004).

Results from the present study suggest that sardines from the northwest coast of Portugal seem to have a higher food availability throughout the year, which is related to increased production as a consequence of upwelling events and higher river runoff there, than do sardines from the south coast. However, studies on the regional differences in reproduction and growth of sardines indicate that sardines grow faster and reach maturity earlier off the south coast (Silva 2003, Silva et al. 2006), which could indicate a higher food availability, but is in contrast to the results of this study. This disparity could mean that growth is not controlled by food availability, but by other variables such as temperature.

\section{Remotely sensed chlorophyll data and sardine diet}

Sardines are able to use filter and particulate feeding depending on prey size, filtering prey $<724 \mu \mathrm{m}$ and particulate feeding on prey $>780 \mu \mathrm{m}$ (Garrido et al. 2007). The observed bimodal distribution of prey size classes suggests that both feeding modes are used in the wild. However, the numerical dominance of small prey in the stomachs and the great importance of prey $<750 \mu \mathrm{m}$ to sardine dietary carbon suggest that filter feeding is the main feeding mode employed by sardines. This implies that the composition and abundance of stomach contents would reflect ambient plankton availability, an assumption that enabled us to compare sardine diet and remotely sensed satellite-derived chl a concentrations. Weak positive relations were found between carbon content of autotrophic phytoplankton, feeding intensity and chl a concentration.

Several factors can contribute to limit the direct relation between satellite chl a data and sardine feeding intensity and diet composition, ranging from the inher- 
ent limitations of remote sensing such as the vertical phytoplankton distribution, the diversity and physiology of the plankton species, suspended sediments and aerosols (Gregg \& Casey 2004), to the limitations associated with fish behaviour, namely the use of 2 different feeding modes. Despite these limitations, chl a data provided by SeaWIFS have proven to be very useful in characterizing physical oceanographic processes and relating enhanced productivity areas and periods with fish yield and distribution, especially when combined with sea surface temperature data to detect areas of plankton concentration (e.g. Hendiarti et al. 2004, Solanki et al. 2005, Ware \& Thomson 2005, Palacios et al. 2006, Zainuddin et al. 2006).

The matching between the temporal variability in sardine stomach mass and the remotely sensed chlorophyll data observed here indicates that the potential use of satellite data to infer sardine distribution and feeding intensity should be further investigated given the fact that food limitation for planktivorous fish determined by variations in primary production is to be expected in Eastern Boundary Current systems (Carr 2002).

Acknowledgements. This study was made under the auspices of the IPIMAR Programme PELAGICOS, funded by the Portuguese Ministry of Science (MLE 013/2000). S.G. is grateful to the National Agriculture and Fisheries Research InstituteIPIMAR for its financial support in the form of a grant within the research programme PELAGICOS and the project NeoMAv, co-financed by FEDER and the EU. The authors are indebted to the team of the National Sampling Program that routinely perform the sardine biological sampling, and to L. Dias for helping with the stomach content weighing. We thank F. Quintela, G. Vilarinho, A. Morais, S. Palma and A. Silva for their help with phytoplankton and zooplankton identification. Thanks are due to P. Ramos for the identification of the stomach parasites. Thanks also to the SeaWiFS Project and the Distributed Active Archive Center at the Goddard Space Flight Center for the production and distribution of the satellite ocean colour data. Four anonymous referees also helped improve this work.

\section{LITERATURE CITED}

Alheit J (1987) Egg cannibalism versus egg predation: their significance in anchovies. S Afr J Mar Sci 5:467-470

Bandarra NM, Batista I, Nunes ML, Empis JM, Christie WW (1997) Seasonal changes in lipid composition of sardine (Sardina pilchardus). J Food Sci 62(1):40-42

Bode A, Carrera P, Lens S (2003) The pelagic foodweb in the upwelling ecosystem of Galicia (NW Spain) during spring: natural abundance of stable carbon and nitrogen isotopes. ICES J Mar Sci 60:11-22

Bode A, Alvarez-Ossorio MT, Carrera P, Lorenzo J (2004) Reconstruction of the trophic pathways between plankton and the North Iberia sardine (Sardina pilchardus) using stable isotopes. Sci Mar 68:165-178

Borges MF, Santos AMP, Crato N, Mendes H, Mota B (2003) Sardine regime shifts off Portugal: a time series analysis of catches and wind conditions. Sci Mar 67 (Suppl 1):235-244

Brooks JL, Dodson SI (1965) The effect of a marine planktivore on lake plankton illustrates theory of size, competition, and predation. Science 150(3692):28-35

Carr ME (2002) Estimation of potential productivity in Eastern Boundary Currents using remote sensing. Deep-Sea Res II 49(1-3):59-80

Carrera P, Porteiro C (2003) Stock dynamic of the Iberian sardine (Sardina pilchardus W.) and its implication on the fishery off Galicia (NW Spain). Sci Mar 67(Suppl 1):245-258

Costa PR, Garrido S (2004) Domoic acid accumulation in the sardine (Sardina pilchardus) and its relationship to Pseudonitzschia diatom ingestion. Mar Ecol Prog Ser 284:261-268

Cunha ME (2001) Physical control of biological processes in a coastal upwelling system: comparison of the effects of coastal topography, river run-off and physical oceanography in the northern and southern parts of Portuguese coastal waters. $\mathrm{PhD}$ dissertation, University of Lisbon

Cunha ME, Garrido S, Pissarra J (2005) The use of stomach fullness and colour indices to assess Sardina pilchardus feeding. J Mar Biol Assoc UK 85:425-431

Fiúza A (1983) Upwelling patterns off Portugal. In: Suess E, Thiede J (eds) NATO Conference Series IV, Marine Science (10a), Coastal upwelling: its sediment record. Plenum Publishing Corporation, p 85-98

Fiúza AFD, DeMacedo ME, Guerreiro MR (1982) Climatological space and time-variation of the Portuguese coastal upwelling. Oceanol Acta 5(1):31-40

Flinkman J, Vourinen I, Christiansen M (1994) Calanoid copepod eggs survive passage through fish digestive tracts. ICES J Mar Sci 51:127-129

Garrido S (2003) Alimentação de Sardina pilchardus (Walbaum, 1792) ao largo da costa continental portuguesa e implicações da condição nutricional das fêmeas na qualidade dos oócitos. MS thesis, Instituto de Ciências Biomédicas de Abel Salazar (ICBAS), Porto

Garrido S, Marçalo A, Zwolinski J, van der Lingen CD (2007) Laboratory investigations on the effect of prey size and concentration on the feeding behaviour of Sardina pilchardus. Mar Ecol Prog Ser 330:189-199

Gregg WW, Casey NW (2004) Global and regional evaluation of the SeaWiFS chlorophyll data set. Remote Sens Environ 93(4):463-479

Guisande C, Vergara AR, Riveiro I, Cabanas JM (2004) Climate change and abundance of the Atlantic-Iberian sardine (Sardina pilchardus). Fish Oceanogr 13(2):91-101

Hayse JW (1990) Feeding habits, age, growth, and reproduction of Atlantic spadefish Chaetodipterus faber (Pisces, Ephippidae) in South Carolina. Fish Bull 88(1):67-83

Hendiarti N, Siegel H, Ohde T (2004) Investigation of different coastal processes in Indonesian waters using SeaWiFS data. Deep-Sea Res II 51(1-3):85-97

Hunter JR, Kimbrell CA (1980) Egg cannibalism in the northern anchovy Engraulis mordax. Fish Bull 78(3):811-816

Huntley ME, Lopez MDG (1992) Temperature-dependent production of marine copepods: a global synthesis. Am Nat 140:201-242

ICES (International Council for the Exploration of the Sea) (2000) Report of the study group on the estimation of spawning stock biomass of sardine and anchovy. ICES Comm Meet 2000/ACFM:5:1-546

ICES (International Council for the Exploration of the Sea) (2003) Report of the study group on the estimation of spawning stock biomass of sardine and anchovy. ICES Comm Meet 2003/G17:1-107

ICES (International Council for the Exploration of the Sea) (2006) Report of the working group on the assessment of mackerel, horse mackerel, sardine and anchovy. ICES Comm Meet 2006/ACFM:08:1-631 
Kiyofuji H, Hokimoto T, Saitoh SI (2006) Predicting the spatiotemporal chlorophyll a distribution in the Sea of Japan based on SeaWiFS ocean color satellite data. IEEE Geosci Remote Sens Lett 3:212-216

Legendre P, Legendre L (1998) Numerical ecology, 2nd English edn. Elsevier Science, Amsterdam

Lindley JA (1998) Dry weights, carbon and nitrogen content of decapod larvae from the plankton. J Mar Biol Assoc UK 78: 341-344

Moita MT (2001) Estrutura, variabilidade e dinâmica do fitoplâncton na costa de Portugal continental. PhD thesis, University of Lisbon

Napier IR (1993) The organic carbon content of gravel bed herring spawning grounds and the impact of herring spawn deposition. J Mar Biol Assoc UK 73(4):863-870

Palacios DM, Bograd SJ, Foley DG, Schwing FB (2006) Oceanographic characteristics of biological hot spots in the North Pacific: a remote sensing perspective. Deep-Sea Res II 53(3-4):250-269

Persson A (2000) Possible predation of cysts - a gap in the knowledge of dinoflagellate ecology? J Plankton Res 22(4): 803-809

Relvas P, Barton ED (2002) Mesoscale patterns in the Cape São Vicente (Iberian Peninsula) upwelling region. J Geophys Res 107(C10):3164, doi: 10.1029/2000JC000456

Silva A (2003) Morphometric variation among sardine (Sardina pilchardus) populations from the northeastern Atlantic and the western Mediterranean. ICES J Mar Sci 60(6):1352-1360

Silva A, Santos MB, Caneco B, Pestana G, Porteiro C, Carrera $\mathrm{P}$, Stratoudakis Y (2006) Temporal and geographic variability of sardine maturity at length in the northeastern Atlantic and the western Mediterranean. ICES J Mar Sci 63(4): $663-676$

Silva E (1954) Some notes on the food of the pilchard Sardina pilchardus (Walb.) of the Portuguese coasts. Rev Fac Cienc Univ Lisb Ser 2(4):281-294

Smayda TJ (1978) From phytoplankters to biomass. In: Sournia A (ed) Phytoplankton manual. UNESCO, New York, p 273-279

Editorial responsibility: Otto Kinne, Oldendorf/Luhe, Germany
Sokal RR, Rohlf FJ (1995) Biometry - the principles and practice of statistics in biological research, 3rd edn. WH Freeman, New York

Solanki HU, Mankodi PC, Nayak SR, Somvanshi VS (2005) Evaluation of remote-sensing-based potential fishing zones (PFZs) forecast methodology. Cont Shelf Res 25(18): $2163-2173$

Thomas D, Franz B (2005) Overview of SeaWiFS data processing and distribution. Available at http://oceancolor.gsfc. nasa.gov/DOCS/SW_proc.html

Valdés Szeinfeld E (1991) Cannibalism and intraguild predation in clupeoids. Mar Ecol Prog Ser 79:17-26

Valdés Szeinfeld E, Shelton PA, Armstrong MJ, Field JG (1987) Cannibalism in South African anchovy:egg mortality and egg consumption rates. S Afr J Mar Sci 5:613-622

van der Lingen CD (1998) Gastric evacuation, feeding periodicity and daily ration of sardine Sardinops sagax in the southern Benguela upwelling ecosystem. In: Pillar SC, Moloney CL, Payne AIL, Shillington FA (eds) Benguela dynamics: impacts of variability on shelf-sea environments and their living resources. S Afr J Mar Sci 19:305-316

Varela M, Larrañaga A, Costas E, Rodríguez B (1988) Contenido estomacal de la sardina (Sardina pilchardus, Walbaum) durante la campaña Saracus 871 en las plataformas Cantábrica y de Galicia en Febrero de 1987. Bol Inst Esp Oceanogr 5:17-28

Varela M, Alvarez-Ossorio MT, Valdés L (1990) Método para el estudio cuantitativo del contenido estomacal de la sardina. Resultados preliminares. Bol Inst Esp Oceanogr 6: 117-126

Verity PG, Langdon C (1984) Relationships between lorica volume, carbon, nitrogen, and ATP content of tintinnids in Narragansett Bay. J Plankton Res 6(5):857-869

Ware DM, Thomson RE (2005) Bottom-up ecosystem trophic dynamics determine fish production in the northeast Pacific. Science 308(5726):1280-1284

Zainuddin M, Kiyofuji H, Saitoh K, Saitoh SI (2006) Using multi-sensor satellite remote sensing and catch data to detect ocean hot spots for albacore (Thunnus alalunga) in the northwestern North Pacific. Deep-Sea Res II 53(3-4): $419-431$

Submitted: November 8, 2006; Accepted: August 3, 2007

Proofs received from author(s): January 22, 2008 